\title{
Synthesis and Swelling Behavior of Sodium Alginate/Poly(vinyl alcohol) Hydrogels
}

\section{Sodyum Aljinat/Poli(vinil alkol) Hidrojellerinin Sentezi ve Şişme Davranışları}

\author{
(D) Lachakkal Rudrappa SHIVAKUMARA, (D) Thippaiah DEMAPPA* \\ University of Mysore, Sir. M. Visvesvaraya Post-Graduate Center, Department of Post Graduate Studies and Research in Polymer Science, Tubinakere, \\ Mandya, Karnataka, India
}

\begin{abstract}
Objectives: Hydrogels are macromolecular networks able to absorb and release water/biological fluids in a reverse-phase manner, in response to specific environmental stimuli. Such stimuli-sensitive behavior makes hydrogels interesting for the design of smart devices applicable to a variety of technological fields. They are able to absorb and retain $10-20 \%$ and up to 1000 times the water or biological fluids than their dry weight can. The aim of this study was to extend the work on drug delivery in the stomach at $\mathrm{pH}$ 2-2.2.

Materials and Methods: The authors synthesized sodium alginate (SA)/poly(vinyl alcohol) (PVA) hydrogels. These hydrogels were characterized by fourier transform infrared spectroscopy and scanning electron microscopy, and the swelling properties of the hydrogels were examined at different $\mathrm{pH}$ values, in different salts, at different temperatures, and in different acids and bases.

Results: The authors studied and reported the swelling effects or variations such as the effects of salts, acids, bases, temperature, and pH. The results for the crosslinking agent glutaraldehyde showed that $8 \mathrm{~mL}$ of glutaraldehyde had a higher swelling rate compared to that of $10 \mathrm{~mL}$ and 12 $\mathrm{mL}$.

Conclusion: In this work the authors studied the swelling degree in different acids and bases. It is concluded that the degree of swelling decreases with increases in the concentration of glutaraldehyde and also depending on the concentrations of the acids. The swelling degrees of PVA/SA hydrogels gradually increase with increases in the concentrations of acids (low $\mathrm{pH}$ ). The swelling of hydrogels decreases with increases in $\mathrm{pH}(>7)$ or at high alkaline. Based on the results for salt solutions the swelling behavior was found to be in the order: $\left.\left.\left.\mathrm{K}^{+}\right\rangle \mathrm{Na}^{+}\right\rangle \mathrm{Ca}^{2+}\right\rangle \mathrm{Mg}^{2+}$.
\end{abstract}

Key words: Swelling, pH, crosslinking agent, buffer solution, sodium alginate, PVA

öz

Amaç: Hidrojeller, belirli çevresel uyaranlara yanıt olarak su/biyolojik sıvıları ters fazda emebilen ve serbest bırakabilen makromoleküler ağlardır. Bu tür uyaranlara duyarlı davranış, çeşitli teknolojik alanlara uygulanabilen akıllı cihazların tasarımı için hidrojelleri ilginç kılar. Kuru ağırlığından \%1020 ve 1000 veya daha fazla su veya biyolojik sıvıları emebilir ve tutabilirler. Bu çalışmanın amacı, midede ilaç dağıtım çalışmalarını pH 2-2.2'sinde genişletmektir.

Gereç ve Yöntemler: Yazarlar sentezlenmiş sodyum aljinat (SA)/poli(vinil alkol) (PVA) hidrojellerdir. Bu hidrojeller fourier dönüșümü kızı̈ötesi spektroskopisi, taramalı elektron mikroskobu, farklı pH'larda hidrojellerin şişme özellikleri, tuzlar, farklı sıcaklık, farklı asitler ve bazlar ile karakterize edilir.

Bulgular: Yazarlar, tuzların, asitlerin, bazların, sıcaklığın ve pH'ın etkisi gibi șișme etkilerini veya varyasyonlarını incelediler ve rapor ettiler. Çapraz bağlama maddesi glutaraldehitin etkisi, $8 \mathrm{~mL}$ glutaraldehidin, $10 \mathrm{~mL}$ ve 12 mL'ninkiyle karşılaştırıldığında en yüksek şişme oranına sahip olduğunu göstermektedir.

Sonuç: Bu çalışmada yazarlar farklı asit ve bazlarda şişme derecesini incelemişlerdir. Glutaraldehit konsantrasyonundaki artışla ve aynı zamanda asit konsantrasyonuna bağlı olarak şişlik derecesinin azaldığı sonucuna varılmıştır. PVA/SA hidrojellerinin şișme derecesi, asit konsantrasyonundaki artışla (düşük $\mathrm{pH}$ ) kademeli olarak artmaktadır. Hidrojellerin şişmesi pH'ın ( $>7)$ artmasıyla veya yüksek alkali ile azalır. Tuz çözeltilerinin etkisinde şişme davranışının sırasıyla: $\left.\left.\left.\mathrm{K}^{+}\right\rangle \mathrm{Na}^{+}\right\rangle \mathrm{Ca}^{2+}\right\rangle \mathrm{Mg}^{2+}$ olduğu bulunmuştur.

Anahtar kelimeler: Şişme, pH, çapraz bağlama maddesi, tampon çözelti, sodyum aljinat, PVA

*Correspondence: E-mail: tdemappa2003@yahoo.co.in - shivu9686178586@gmail.com, Phone: 9686178586

Received: 24.11.2017, Accepted: 09.05.2018

๑Turk J Pharm Sci, Published by Galenos Publishing House. 


\section{INTRODUCTION}

Hydrogels have been used in various chemical and biomedical applications in ophthalmology as contact lenses and surgical sutures, as well as in numerous other areas like agricultural applications.

Sodium alginate (SA) is an anionic copolymer composed of 1,4-linked $\beta$-D-mannuronic acid (M-blocks) and $\alpha$-L-guluronic acid (G-blocks), interspersed with regions of alternating structure. Gel formation and three-dimensional network structures occur when divalent ions $\left(\mathrm{Ca}^{2+}, \mathrm{Ba}^{2+}, \mathrm{Fe}^{2+}, \mathrm{Si}^{2+}\right.$, etc.) or trivalent ions ( $\mathrm{Al}^{3+}$, etc.) crosslink with $\mathrm{G}$-blocks in the polymer chain. Such binding zones between G-blocks are often referred to as "egg boxes". These crosslinked ions stabilize alginate chains, forming a gel structure, with more freely movable chains that bind and entrap large quantities of water or biological fluids. The gel formation (gelification) process is characterized by the eviction of water. The softer, more fragile, and lower porosity gels are made of M-rich alginate groups. This is due to the lower binding strength between the polymer chains and to the higher flexibilities of the molecules. The gel formation process is highly dependent on diffusion of gel formation ions into the polymer network. Visco-elasticity and transmittance of alginate structures are highly affected by the $M / G$ ratio. Alginic acid and its salts of sodium and calcium are used in the medical, pharmaceutical, cosmetic, and food industries because of its nontoxicity and biocompatibility. ${ }^{2}$ The main advantage of hydrogels is that they possess a degree of flexibility very similar to that of natural tissues, due to their significant water content. Their stimuli-sensitive behavior makes hydrogels interesting for the design of smart devices applicable to a variety of technological fields.

Hydrogels are, in general, materials composed of threedimensional hydrophilic polymer networks and water that fills the free spaces inside this network. Hydrogels are able to absorb and retain $10-20 \%$ up to 1000 times the water or biological fluids than their dry weight can. Hydrogels respond reversibly to slight changes in the properties of surrounding media; hence they are called "intelligent materials". This ability means hydrogels have found many applications in industry and in pharmaceuticals, for example as controlled drug delivery systems. $^{3}$ The swelling and dehydration behavior is one of the most important properties of hydrogels. ${ }^{4}$ Applications of hydrogels include drug delivery systems (slow drug release), wound dressings, dental applications, transdermal implants, injectable polymers, contact lenses, superabsorbents, and environmentally sensitive hydrogels. ${ }^{5-9}$ Hydrogels interact with aqueous solutions and swell to a certain equilibrium and retain a significant proportion of water within their structure..$^{10} \mathrm{SA}$ is a hydrophilic polysaccharide, a natural polymer, composed of a mannuronic acid unit. This compound has been used for a long time in various industries, such as agriculture, food, medicine, textile, cosmetics, and printing. SA is also used as a thickener, stabilizer, and emulsifier and for microencapsulation, as well as in slow release drug delivery systems and fertilizers." SA has a molecular structure similar to collagen; therefore it can make the skin smooth and elastic and can accelerate wound healing, and it can be used as a natural alternative product for health care and cosmetics. ${ }^{12-14} \mathrm{SA}$ is of biological origin and has good characteristics, such as biocompatibility, biodegradability, and gel-forming ability. Poly(vinyl alcohol) (PVA) is a hydrophilic polymer and is of great interest for use as a biomaterial because of its good biocompatible properties. It has chemical stability, high durability, and a high degree of swelling in water or biological fluids. PVA is nontoxic to viable cells, noncarcinogenic, has high biocompatibility, and has a consistency similar to soft tissue, film forming with high mechanical strength, and long-term temperature stability. Its three-dimensional network enables diffusional exchange of nutrients and waste products with the surrounding environment, and it is used in various biomedical, pharmaceutical, biotechnological, and other industrial fields. ${ }^{15-20}$ However, even though PVA is a biomaterial it is brittle in nature; therefore, it needs to be blended with other polymers or by copolymerization, e.g., with SA, to obtain a better property that can be used to encapsulate or entrap or to immobilize an enzyme or drug in micron or submicron (nano) size, to keep the constancy of its activity, or to prevent activity decreases drastically. Hence it works more effectively and efficiently compared to when it is in free condition. ${ }^{6,21,22}$ The crosslinked alginate hydrogels have been used as a controlled release medium for drugs, ${ }^{23-27}$ pesticides, ${ }^{28}$ superabsorbent filament fibers, ${ }^{29}$ and flocculants. ${ }^{30}$

In the presence of an aqueous solution, the polymer chains absorb water and the association, dissociation, and binding of various ions to polymer chains cause the hydrogel to swell. The shrinking and swelling properties of hydrogels are currently being exploited in a number of applications including the control of microfluidic flow, ${ }^{31}$ muscle-like actuators, ${ }^{32,33}$ filtration/ separation, ${ }^{34}$ and drug delivery. ${ }^{35,36}$ The structure and properties of hydrogels are similar to those of many biological tissues such as cartilage and the corneal stroma in the eye. ${ }^{37,38}$ Hydrogels are accomplished through large reversible deformation in response to changes in several environmental factors. ${ }^{39}$ For example, hydrogel size is sensitive to $\mathrm{pH}$, temperature, concentration of salts, and electric fields.

\section{EXPERIMENT}

\section{MATERIALS AND METHODS}

\section{Materials}

SA, PVA molecular weight 125.000, and glutaraldehyde (25\%) were purchased from S.D. Fine Chem Limited, Mumbai, India. Hydrochloric acid, perchloric acid, sodium hydroxide, and acetic acid were purchased from Reachem Laboratory Chemicals Private Ltd, Chennai, India. Calcium chloride, magnesium chloride, sodium chloride, and potassium chloride were purchased from E-Merck Limited, Mumbai, India, and double distilled water was used throughout the experiment.

\section{Methods}

\section{Preparation of SA/PVA hydrogels}

First $7 \mathrm{~g}$ of SA was dissolved in $100 \mathrm{~mL}$ of water with constant stirring. Then $9 \mathrm{~g}$ of PVA was dissolved in the same solution with stirring for about $3 \mathrm{~h}$ at $80^{\circ} \mathrm{C}$ to $85^{\circ} \mathrm{C}, 12 \mathrm{~mL}$ of glutaraldehyde 
(25\%) was added to the same solution, and this solution was kept at $80^{\circ} \mathrm{C}$ for $3 \mathrm{~h}$. After $3 \mathrm{~h}$ the obtained hydrogel was washed with distilled water and ethanol to remove the excess monomer and crosslinking agent. After washing 2-3 times the hydrogel was dried at $40^{\circ} \mathrm{C}$ in an oven. Likewise the different SA/PVA hydrogels synthesized with varying volume of glutaraldehyde (10 and $8 \mathrm{~mL}$ ) were used for swelling studies.

\section{CHARACTERIZATION}

\section{Fourier-transform infrared spectroscopy}

The FTIR spectra of the SA, PVA, and the crosslinked hydrogel samples were recorded in the range of 4000 to $500 \mathrm{~cm}^{-1}$ to provide the proof of hydrogels (Figure 1).

\section{Surface morphology of hydrogels}

The surface morphology of the SA, PVA, and glutaraldehyde crosslinking hydrogels were investigated using scanning electron microscopy (SEM) (SEM Zeiss, LS15) (Figure 2).

\section{Swelling behavior of hydrogels}

For the swelling behavior of hydrogels, the swelling ratio of the hydrogel samples was measured at different temperatures in different solvents by gravimetric method. Pre-weighed dry hydrogel samples were immersed in excessive different solutions and left undisturbed for $24 \mathrm{~h}, 48 \mathrm{~h}$, and $72 \mathrm{~h}$ at different temperatures like room temperature, $30^{\circ} \mathrm{C}, 37^{\circ} \mathrm{C}$, and $40^{\circ} \mathrm{C}$ until constant values were obtained. Degree of swelling rate can be calculated by the following equation:

$$
\% D S=\left(W_{2}-W_{1}\right) / W_{1} \times 100 \ldots \ldots \ldots \ldots \ldots \ldots \ldots \ldots . . . .(E q u a t i o n ~ 1)
$$

$\%$ DS is the degree of swelling expressed in a percentage and $W_{1}$ and $W_{2}$ are the masses of sample before and after swelling, respectively (Figures 3 to 5 ) (Table 1).

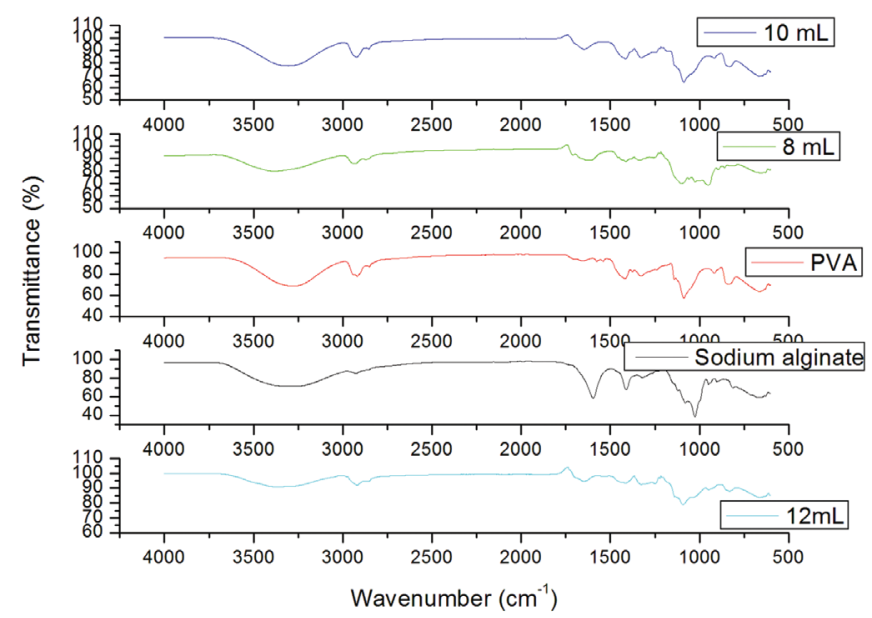

Figure 1. FTIR spectra of pure SA, PVA, 12\% glutaraldehyde crosslinked, $10 \%$ glutaraldehyde crosslinked, and $8 \%$ glutaraldehyde crosslinked hydrogels

FTIR: Fourier transform infrared spectroscopy, SA: Sodium alginate, PVA: Poly(vinyl alcohol)

\section{Swelling at various $\mathrm{pHs}$}

The solution was adjusted to acidic, basic, and neutral $\mathrm{pH}$ by diluting with phosphate buffer $(\mathrm{pH} 3.2, \mathrm{pH} 7, \mathrm{pH} \mathrm{2}$, and $\mathrm{pH} 10)$ solutions at room temperature, $30^{\circ} \mathrm{C}, 37^{\circ} \mathrm{C}$, and $40^{\circ} \mathrm{C}$. The $\mathrm{pH}$ values were checked by $\mathrm{pH}$ meter. The dried hydrogel samples were used for the swelling measurement according to Equation (1) (Figure 6).

\section{Swelling in salt solutions}

The swelling capacity of hydrogels was determined in different salt solutions $\left(\mathrm{KCl}, \mathrm{NaCl}, \mathrm{CaCl}_{2}\right.$, and $\mathrm{MgCl}_{2}$ ) and also with various concentrations like $0.4,0.6,0.8,1$, and $1.2 \mathrm{~N}$ according to the above method (Figure 7).

\section{RESULTS}

The authors reported the swelling effects on hydrogels of different salts, acids, bases, temperatures, and $\mathrm{pH}$ values. A higher swelling rate was shown by $8 \mathrm{~mL}$ of glutaraldehyde compared to $10 \mathrm{~mL}$ and $12 \mathrm{~mL}$. Figure 1 shows the FTIR spectra of the molecular interaction between SA and PVA. The surface morphology of the hydrogels was studied using SEM (SEM Zeiss, LS15) as shown in Figure 2; Figures 3 to 5 and Table 1 represent the swelling behavior of the hydrogels at different temperatures, i.e. $30^{\circ} \mathrm{C}, 37^{\circ} \mathrm{C}, 40^{\circ} \mathrm{C}$, and room temperature, with different salts. Figure 6 shows the behavior of the hydrogels at different $\mathrm{pH}$ values.

\section{DISCUSSION}

\section{Fourier transformed infrared spectral analysis}

Figure 1 represents the FTIR spectra, characterizing the molecular interaction of SA and PVA hydrogels. The FTIR spectra of SA show the characteristic absorption peak at $3270.47 \mathrm{~cm}^{-1}$ is for the hydroxyl $(-\mathrm{OH})$ group. The asymmetric and symmetric stretching vibration of the carboxylic (COO-) group is found to be at 1597.36 and $1412 \mathrm{~cm}^{-1}$, respectively. 40,41 The peak at $2925.38 \mathrm{~cm}^{-1}$ represents the $\mathrm{C}-\mathrm{H}$ alkyl stretching bond. ${ }^{42}$ An absorption peak around $2919.05 \mathrm{~cm}^{-1}$ shows the characteristic spectra of PVA. This peak arises from the $\mathrm{C}-\mathrm{H}$ stretching at 1570 to $1420 \mathrm{~cm}^{-1}$ is assigned for $\mathrm{CH}_{2}$ (vinyl group), while the sharp absorption peak at $1150-1050 \mathrm{~cm}^{-1}$ is used for indication of PVA. ${ }^{43}$ In addition, it was found that the peak at $1549-1453 \mathrm{~cm}^{-1}$ is a stretching band for the $\mathrm{CH}_{2}$ group. This band is also found in pure PVA and crosslinked SA/PVA hydrogels. The decrease in wave number of the carbonyl peak from 1652.14 to $1635.24 \mathrm{~cm}^{-1}$ is for the crosslinking of SA/PVA hydrogels. Crosslinking of glutaraldehyde takes place at 2863 to $2750 \mathrm{~cm}^{-1}$.

\section{SEM images}

SEM describes the surface morphology of SA/PVA hydrogels in Figure 2. According to the SEM images (Figure 2a), the pure SA shows a very smooth surface nearly devoid of any surface feature. ${ }^{43}$ In Figure $2 b$ the SEM images of pure PVA show a very smooth, uniform, and nonporous surface structure, which may be attributed to the crystallization of PVA. ${ }^{44}$ However, the addition of SA to PVA hydrogel in different portions provides very tiny pores at the surface and these pores decrease with an increase in glutaraldehyde concentration (Figures $2 c$ to $2 e$ ). 


\section{Effect of $\mathrm{pH}$ on the swelling of hydrogels}

The sensitivity of the hydrogels was measured from $\mathrm{pH} 2$ to $\mathrm{pH}$ 10. No additional ions (through buffer solutions) were added to the medium for setting $\mathrm{pH}$ because the absorbency of an absorbent is strongly affected by ionic strength. Therefore, stock $\mathrm{HCl}(\mathrm{pH} \mathrm{1.0)}$ ) and $\mathrm{NaOH}(\mathrm{pH} 10.0)$ solutions were diluted with distilled water to achieve the preferred acidic or basic $\mathrm{pH}$ values, respectively. In Table 2 and Figure 6, the swelling capacity of hydrogel at $\mathrm{pH} 2$ can be accredited to the high repulsion of anion-anion $\mathrm{COO}$ - groups. At basic conditions $\mathrm{(pH}$ 27 ), most of the carboxylate groups are protonated and the low swelling values of hydrogels can be attributed to the presence of nonionic hydrophilic - $\mathrm{OH}$ and $-\mathrm{COOH}$ groups in the PVA and alginate backbones, respectively. The swelling capacity is decreased with further increase in $\mathrm{pH}(\mathrm{pH} 10$ or $\mathrm{pH}>7)$. Again

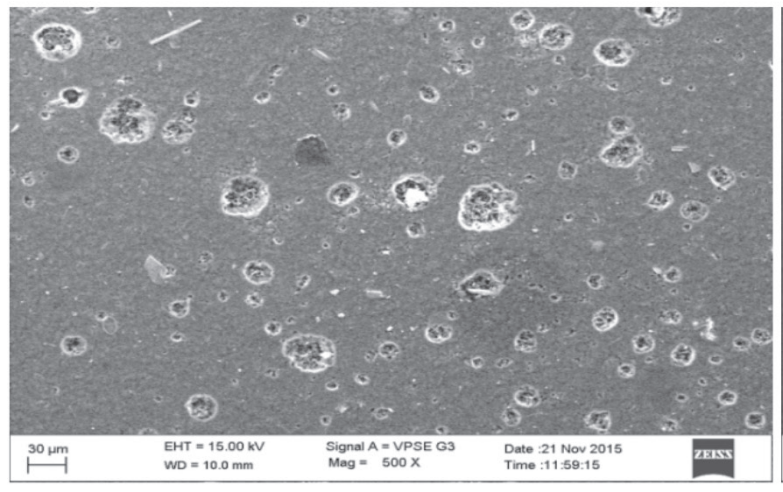

(a)

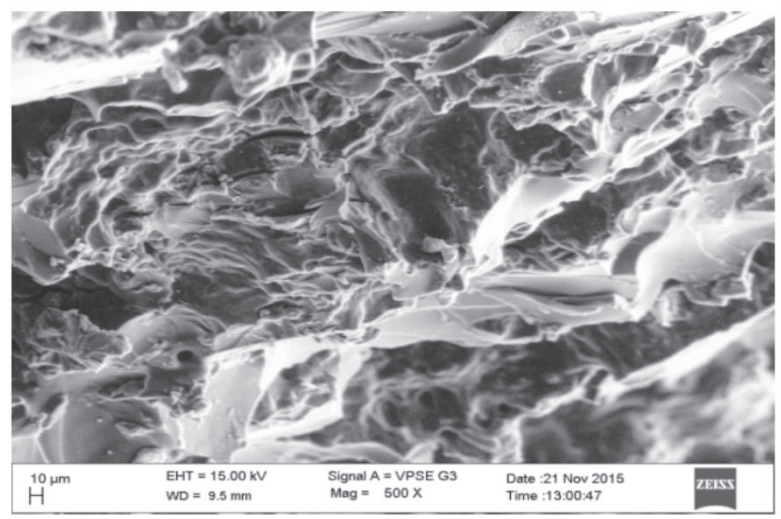

(c)

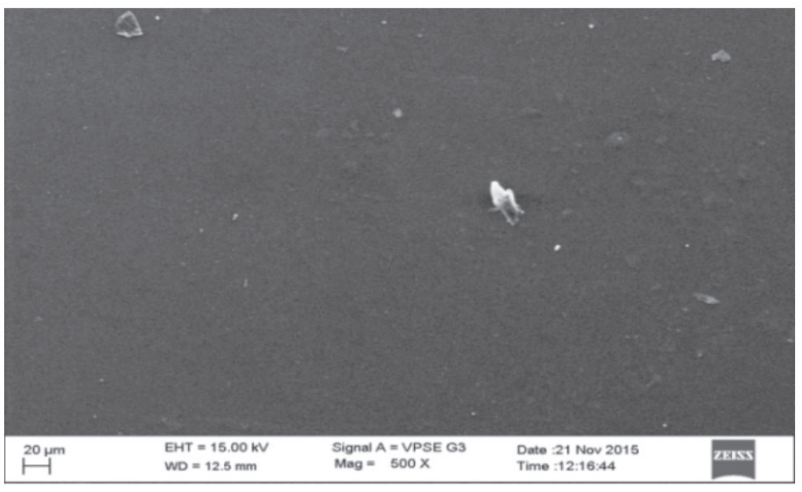

(b)

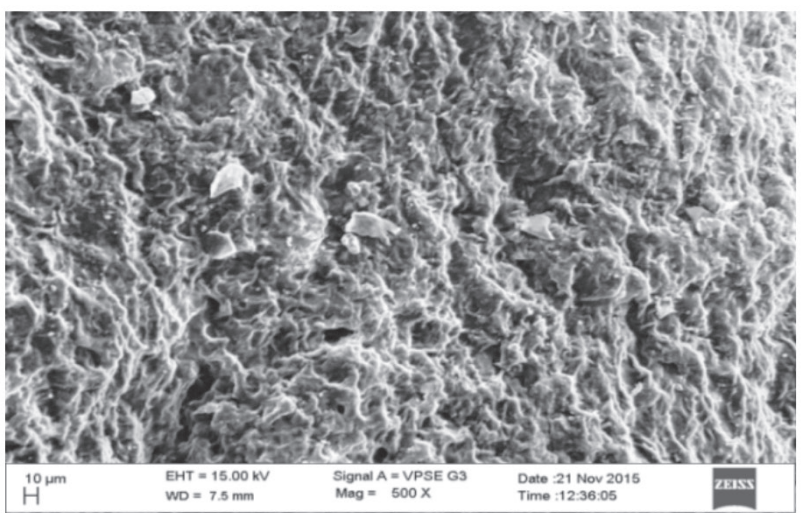

(d)

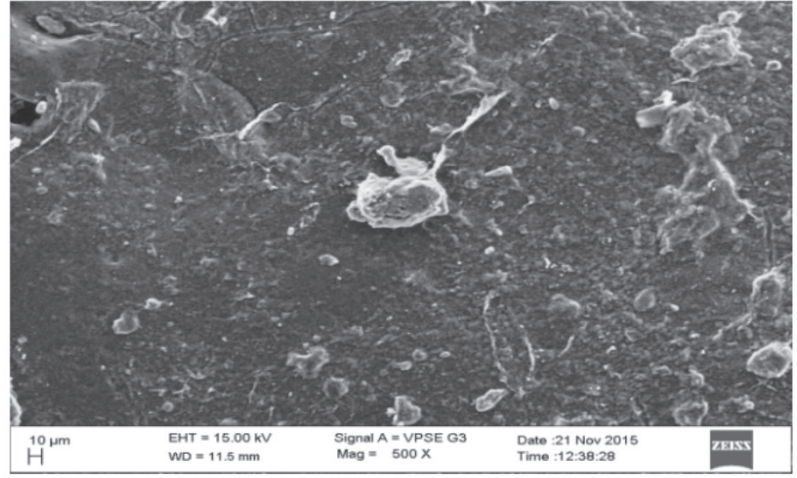

(e)

Figure 2. SEM images of (a) pure sodium alginate, (b) pure PVA, (c) $8 \mathrm{~mL}$ glutaraldehyde crosslinked SA/PVA hydrogel, (d) $10 \mathrm{~mL}$ glutaraldehyde crosslinked SA/PVA hydrogels, (e) $12 \mathrm{~mL}$ glutaraldehyde crosslinked SA/PVA hydrogels 
the swelling loss is due to the counter ions, i.e. $\mathrm{Na}^{+}$, that shield the charge of the carboxylate anions and prevent efficient anion-anion repulsion. As a result, a remarkable decrease in equilibrium swelling is observed.

\section{pH Dependence of the swelling rate of water}

The swelling rate decreased with increasing $\mathrm{pH}$ from 2 to 10; it was evident from the data given. The negatively charged ionic backbones of PVA and SA are more expanded because the protonation of COO- groups is negatively charged. This expanded form makes for easy diffusion of water molecules into the hydrogel network. On the other hand, the -OH groups are mostly in the protonated form and show less polar character at $\mathrm{pH} \geq 7$. Therefore, this results in a polymer with lower affinity to water. Thus, hydrogels are less expanded at $\mathrm{pH} \geq 7$. The increases in swelling ratio are responsible for the theory of electrostatic repulsion between COO- ions in the polymer chains and ionic present in the $\mathrm{pH}$ solution and the ionic osmotic pressure generated from mobile counter ions to charged ions in the network. Thus, the charge density of the hydrogel is diluted, because PVA is not ionic in character (Table 2). Figure 6 shows the swelling studies of phosphate buffered $\mathrm{pH}$ solutions. The glutaraldehyde crosslinked PVA/ SA samples show a gradual increase (in swelling degree at $\mathrm{pH}$ 2 and 3.2) followed by a decrease in swelling degree at $\mathrm{pH} 7$ and 10 at different temperatures $\left(25^{\circ} \mathrm{C}, 30^{\circ} \mathrm{C}, 37^{\circ} \mathrm{C}\right)$. In these studies the $8 \%$ glutaraldehyde crosslinked hydrogel has a high swelling degree compared to the $10 \%$ and $12 \%$ glutaraldehyde crosslinked hydrogels.

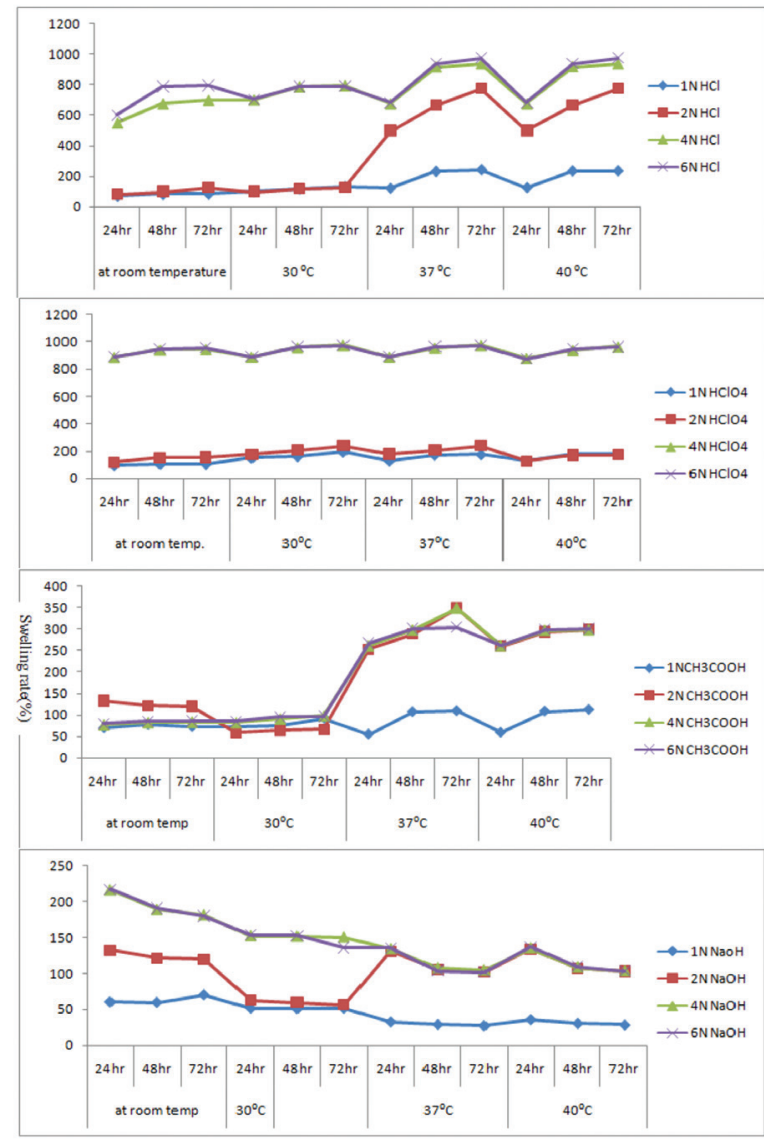

Figure 3. Swelling rate of $8 \mathrm{~mL}$ glutaraldehyde crosslinked hydrogels

Table 1. Data of swelling rate of $8 \mathrm{~mL}$ glutaraldehyde, $10 \mathrm{~mL}$ glutaraldehyde, and $12 \mathrm{~mL}$ glutaraldehyde crosslinked hydrogels at $37^{\circ} \mathrm{C}$

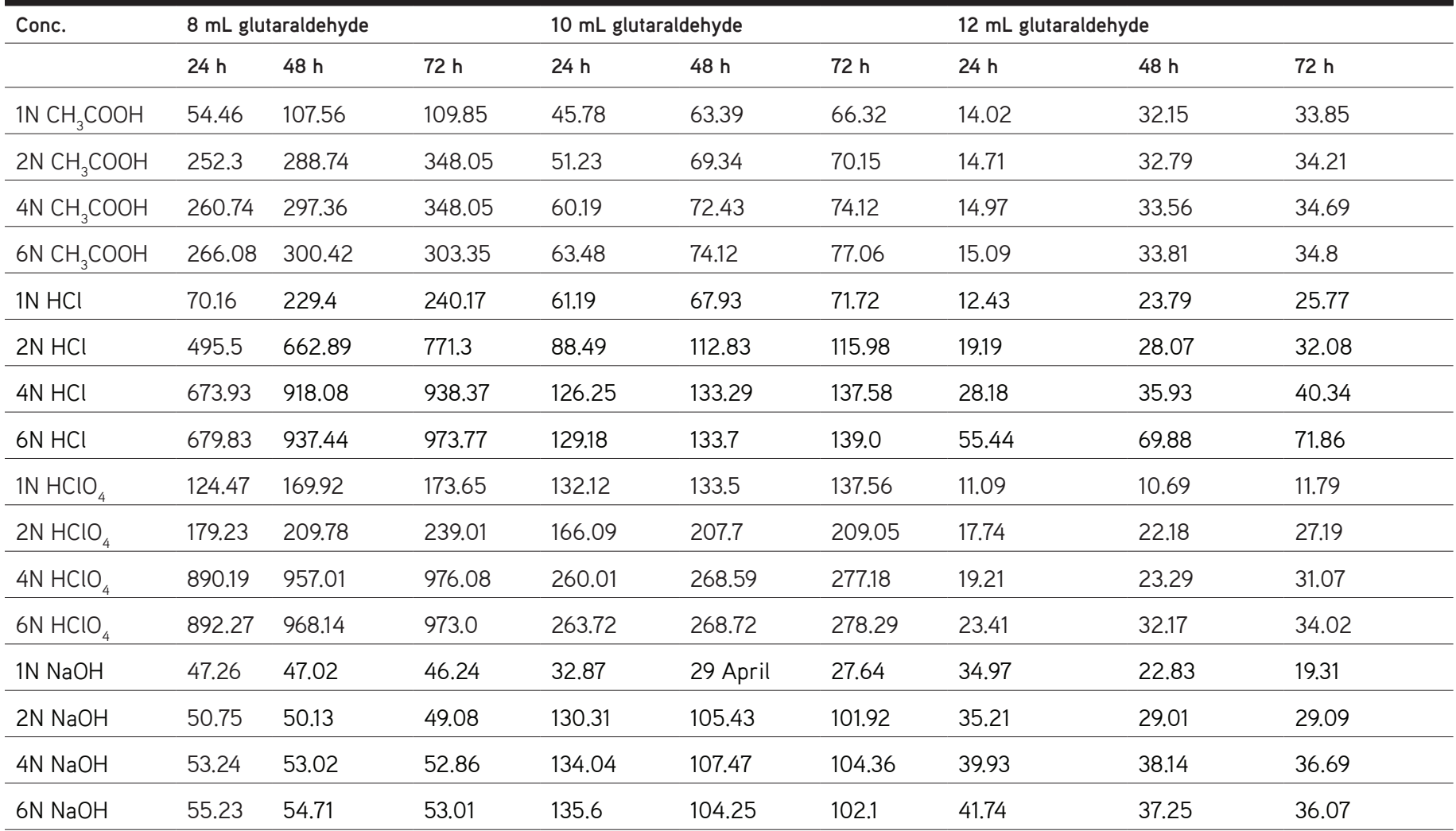




\section{Effect of temperature on the swelling of hydrogels}

It is obvious from Figure 6 that the temperature leading to hydrogels with the highest absorbency is around $37^{\circ} \mathrm{C}$. The swelling capacity of hydrogels decreased with increasing temperature above $37^{\circ} \mathrm{C}$. The increase in swelling rates is dependent on the kinetic energy of the polysaccharide chains, which led to lower soluble content of the hydrogel as well as increasing concentration of glutaraldehyde diffusion rate of SA and PVA backbones. The higher reaction temperature proves the results from higher reactant movement and effective collision. At temperatures about $37^{\circ} \mathrm{C}$, the possible "thermal

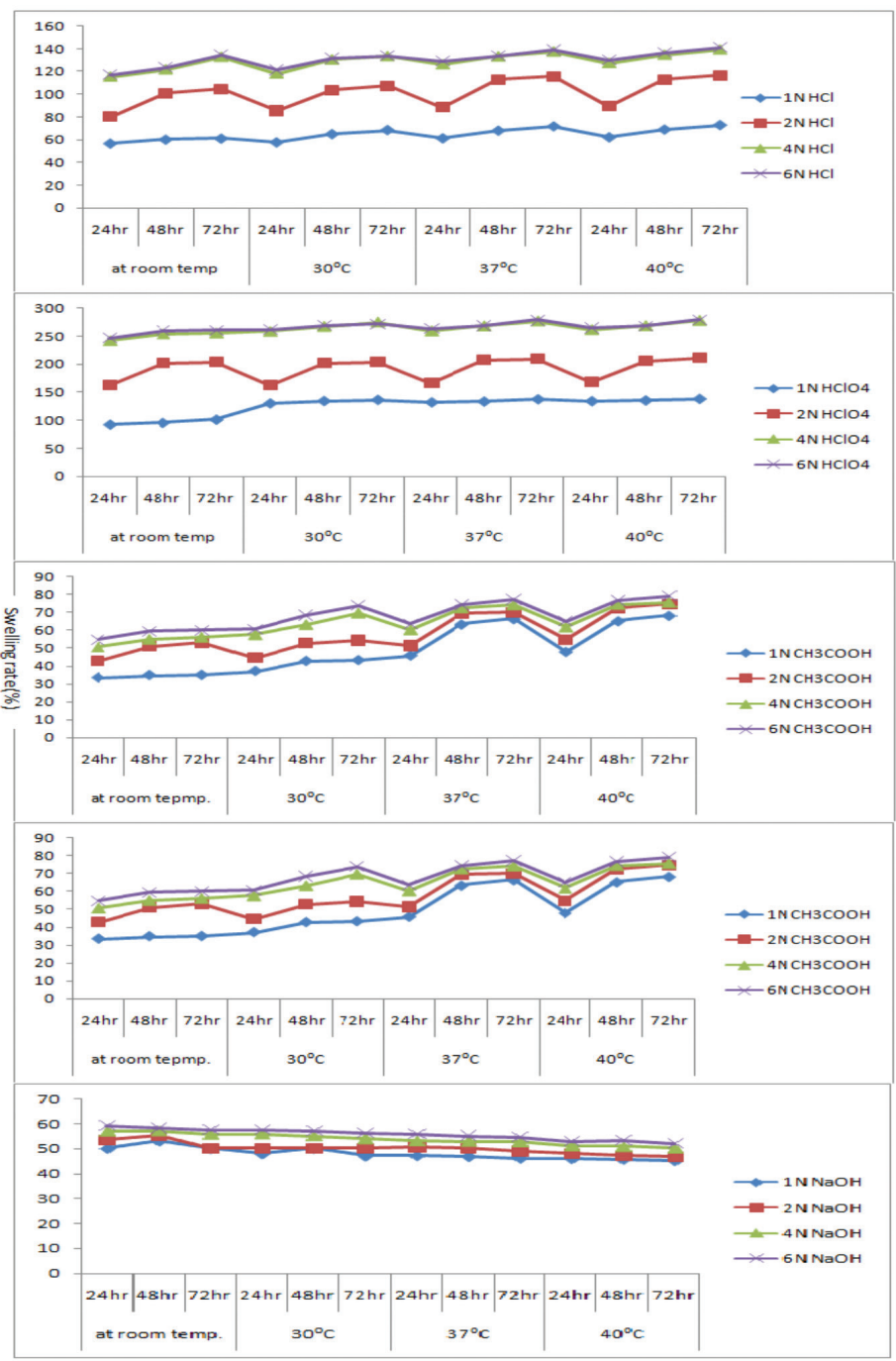

Figure 4. Swelling rate of $10 \mathrm{~mL}$ glutaraldehyde crosslinked hydrogels crosslinking" reaction to polysaccharide backbones may play a major role in the creation of low-swelling hydrogels. In addition, the swelling loss may be related to the increase in crosslinked bond formation of completion of the ester and ether formations by further reaction to the possible mono-ester species with another polysaccharides chain (Scheme 1).

\section{Effect of salt solution on hydrogels}

Hydrogels are considered polyelectrolytes, suggesting that their porosity should decrease as ionic strength increases. SA/PVA hydrogels with various chloride salt solutions are appreciably

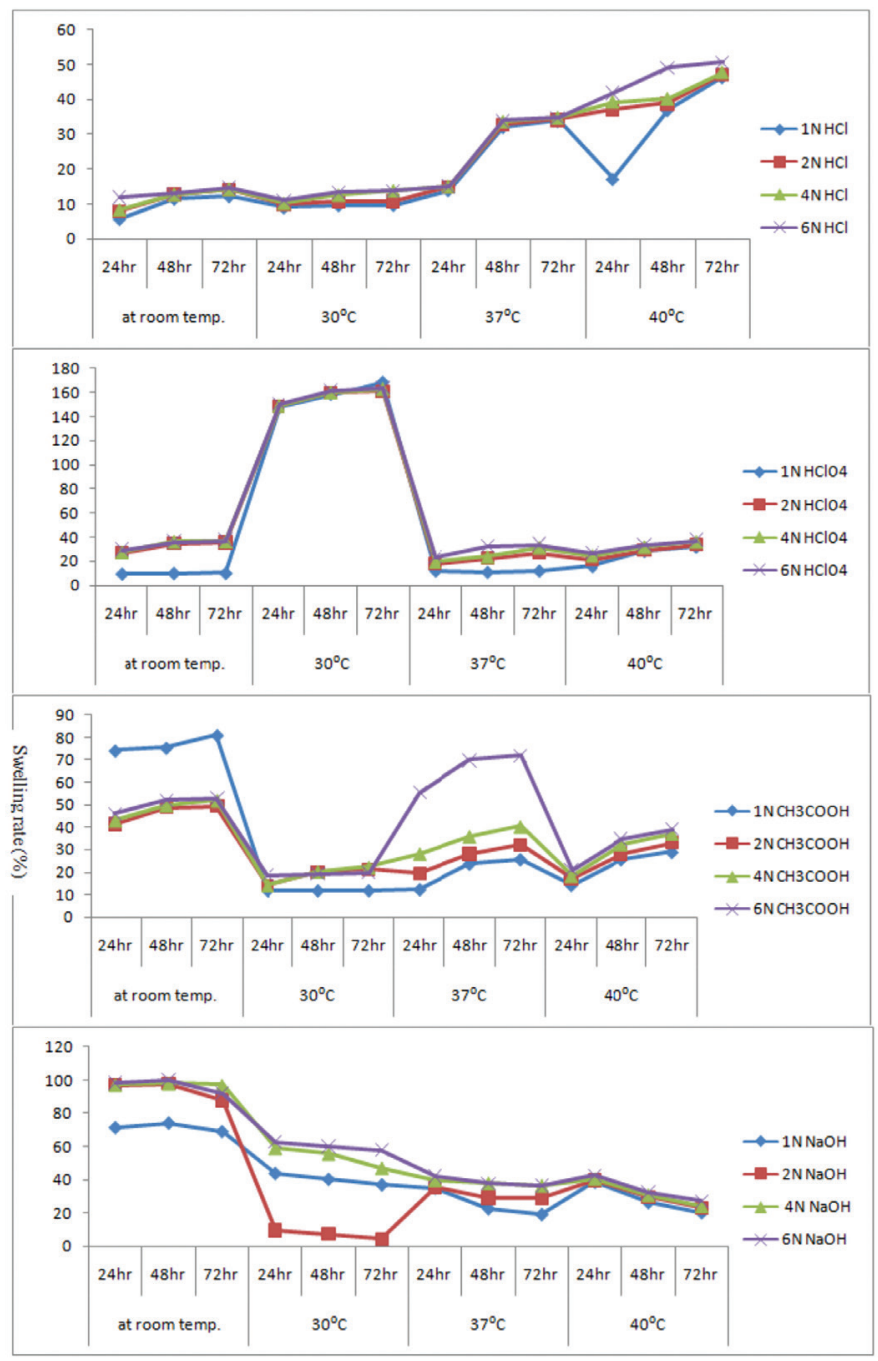

Figure 5. Swelling rate of $12 \mathrm{~mL}$ glutaraldehyde crosslinked hydrogels Table 2. Data of swelling studies of hydrogels in different $\mathrm{pH}$ solutions at $37^{\circ} \mathrm{C}$

\begin{tabular}{|c|c|c|c|c|c|c|c|c|c|}
\hline & \multicolumn{3}{|c|}{$8 \mathrm{~mL}$ glutaraldehyde } & \multicolumn{3}{|c|}{$10 \mathrm{~mL}$ glutaraldehyde } & \multicolumn{3}{|c|}{$12 \mathrm{~mL}$ glutaraldehyde } \\
\hline & $24 \mathrm{~h}$ & $48 \mathrm{~h}$ & $72 \mathrm{~h}$ & $24 \mathrm{~h}$ & $48 \mathrm{~h}$ & $72 \mathrm{~h}$ & $24 \mathrm{~h}$ & $48 \mathrm{~h}$ & $72 \mathrm{~h}$ \\
\hline $\mathrm{pH} 2$ & 120.2 & 121.56 & 122.01 & 75.65 & 76.92 & 77.15 & 75.19 & 76.08 & 77.33 \\
\hline $\mathrm{pH} 7$ & 70.37 & 77.78 & 83.34 & 67.92 & 68.12 & 69.12 & 66.27 & 67.19 & 68.92 \\
\hline $\mathrm{pH} 10$ & 69.24 & 71.34 & 73.45 & 65.26 & 66.74 & 67.05 & 65.48 & 66.47 & 67.19 \\
\hline
\end{tabular}


reduced in swelling compared to those measured in deionized water. This results from a charge screening effect of the additional cations causing anion-anion electrostatic repulsion, which leads to a decreased osmotic pressure difference between the polymer network and the external solution. At a given ionic strength, $\mathrm{Mg}^{2+}$ and $\mathrm{Ca}^{2+}$ contribute more charge than monovalent cations like $\mathrm{Na}^{+}$and $\mathrm{K}^{+}$and induce a bigger drop in intermolecular repulsion and increased interaction between molecules, which, in turn, cause to a large extent the hydrogel collapse. In addition, $\mathrm{Mg}^{2+}$ and $\mathrm{Ca}^{2+}$ can chelate COO- groups, leading to a compact network and causing further shrinking from the hydrogel; on the other hand, we also find that the smaller the radius of atoms of some valent monoatomic cations, the more the water absorption capacity if different cations were $\left.\left.\left.\mathrm{K}^{+}\right\rangle \mathrm{Na}^{+}\right\rangle \mathrm{Ca}^{2+}\right\rangle \mathrm{Mg}^{2+}$ (Table 3 and Figure 7 ). ${ }^{45}$

\section{CONCLUSIONS}

In this work the authors studied the swelling degree in different acids and bases. It is concluded that the degree of

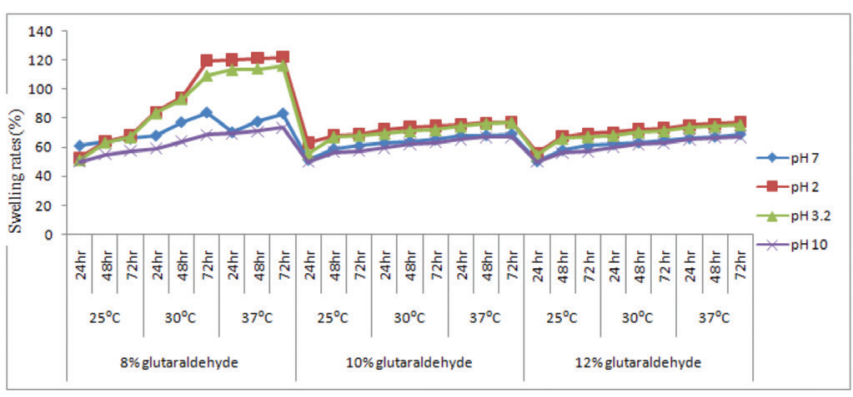

Figure 6. Swelling studies of hydrogels at different $\mathrm{pH}$ values of phosphate buffer solutions

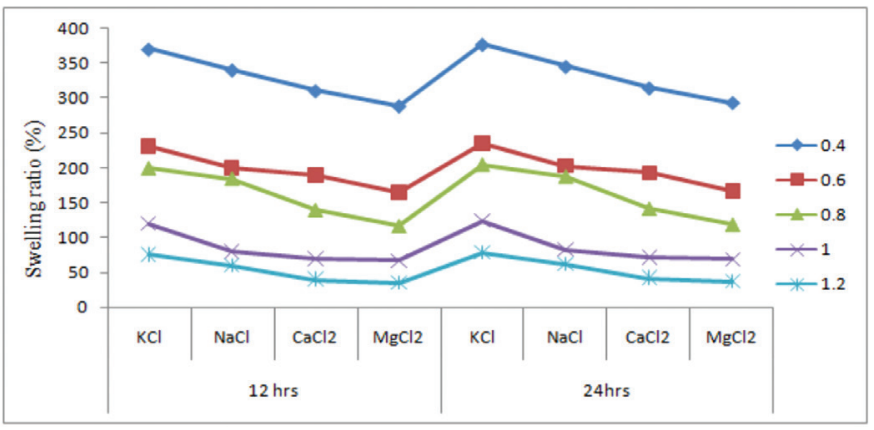

Figure 7. Swelling studies of different concentrated salt solutions at different times swelling decreases with an increase in the concentration of the glutaraldehyde and also depending on the concentration of the acids. Here the swelling degree of PVA/SA hydrogels gradually increases with increases in the concentrations of acids. The aldehyde groups are covalently bonded with the $\mathrm{COO}$ - and $\mathrm{OH}$ - groups of PVA/SA and consequently the swelling degree is significantly reduced. In different concentrations of different salts the swelling rates decreased with increasing concentrations of salts. The swelling rate is in the order of $\left.\left.\left.\mathrm{K}^{+}\right\rangle \mathrm{Na}^{+}\right\rangle \mathrm{Ca}^{2+}\right\rangle \mathrm{Mg}^{2+}$.

\section{Further extension of the work}

This swelling study is to be extended for biomedical and agricultural applications such as drug delivery and controlled release fertilizers. ${ }^{45}$

\section{ACKNOWLEDGEMENTS}

The authors are grateful to the Institution of Excellence for the FTIR and SEM analysis help.

Conflict of Interest: No conflict of interest was declared by the authors.

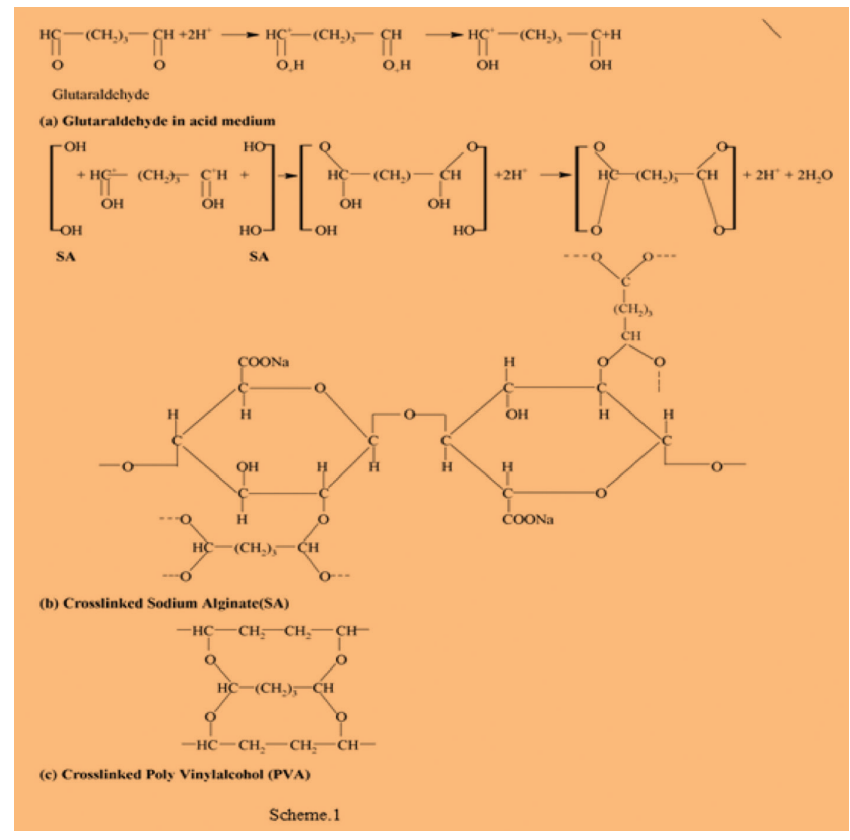

Scheme 1. (a) Glutaraldehyde in acid medium, (b) crosslinked sodium alginate, (c) crosslinked poly(vinly alcohol)

Table 3. Data of swelling studies of hydrogels in different salt solutions

\begin{tabular}{|c|c|c|c|c|c|c|c|c|}
\hline \multirow{2}{*}{ Conc. } & \multicolumn{4}{|l|}{$12 \mathrm{~h}$} & \multicolumn{4}{|l|}{$24 \mathrm{~h}$} \\
\hline & $\mathrm{KCl}$ & $\mathrm{NaCl}$ & $\mathrm{CaCl}_{2}$ & $\mathrm{MgCl}_{2}$ & $\mathrm{KCl}$ & $\mathrm{NaCl}$ & $\mathrm{CaCl}_{2}$ & $\mathrm{MgCl}_{2}$ \\
\hline 0.4 & 370.42 & 340.16 & 310.72 & 288.02 & 377.72 & 345.45 & 314.7 & 293.6 \\
\hline 0.6 & 230.17 & 200.36 & 190.64 & 165 & 235.46 & 203.8 & 193.4 & 167.9 \\
\hline 0.8 & 200.23 & 185.34 & 140.39 & 117.79 & 205.0 & 188.1 & 142.9 & 119.2 \\
\hline 1.0 & 120.14 & 80.08 & 70.06 & 67.58 & 124.19 & 82.5 & 72.01 & 69.1 \\
\hline 1.2 & 75.09 & 60.63 & 40.46 & 35.96 & 78.20 & 62.04 & 42.02 & 37.4 \\
\hline
\end{tabular}




\section{REFERENCES}

1. Serp D, Mueller M, Von Stockar U, Marison IW. Low-temperature electron microscopy for the study of polysaccharide ultrastructures in hydrogels. II. Effect of temperature on the structure of $\mathrm{Ca}^{2+}$-alginate beads. Biotechnol Bioeng. 2002;79:253-259.

2. Wee $S$, Gombotz WR. Protein release from alginate matrices. Adv Drug Deliv Rev. 1998;31:267-285.

3. Dumitriu S. Polymeric Biomaterials, Revised and Expanded. Boca Raton; CRC Press; 2001:1-62.

4. Gemienhart RA, Guo C. Fast swelling hydrogel systems. In: Yui N, Mrsny RJ, Park K, eds. Reflexive Polymers and Hydrogels. New York; CRC Press; 2004:245-258.

5. Rosiak JM, Yoshii F. Hydrogels and medical applications. Nucl Instr Meth Phys Rev. 1999;151:56-64.

6. Silva GS, Fernadez LRV, Higa OZ, Vitolo M, De Queiroz ASA. AlginatePoly (vinyl alcohol) core-shell microspheres for lipase - immobilization. Cebecimat, XVI congreso Brasileiro de Engenhariae Ciencia dos Materials. Porto Alegre - RS de 28 de novembroa 02 de dezembro de; 2004:15.

7. Abbas AA, Lee SY, Selvaratnam L, Yusof N, Kamaru T. Porous PVAchitosan based hydrogels as an extracellular matrix scaffold for cartilage regeneration. European Cells and materials. 2008;16(Suppl 2):50.

8. Ustundag GC, Karaca E, Ozbek S, Cavusoglu I. In vivo evaluation of electrospun Poly (vinyl alcohol) / sodium alginate nanofibrous mat a wound Dressing. Tekstil ve Konveksiyon. 2010;4:290-298.

9. Sariri R. Physicochemical characteristics and Biomedical applications of hydrogel. A review. J Phys Theor Chem IAU Iran. 2011;8:217-231.

10. Tombs MP, Harding SE. An Introduction to Polysaccharide Biotechnology. Taylor and Francis UK; 1999:183.

11. Cunha AG, Gandini A. Turning polysaccharides into hydrophobic materials: a critical review. Part 2. Hemicellulose, chitin/chitosan, starch, pectin and alginates. Cellulose. 2001;17:1045-1065.

12. Cha DS, Choi JH, Chinnan MS, Park HJ. Antimicrobial film based on $\mathrm{Na}$-alginate and K- carrageenan. Lebensmittel Wissenschaft und Technologie. 2002;35:715- 719.

13. Boninsegna S, Dal Toso RD, Monte RD, Carturan G. Alginate microspheres loaded with animal cells and coated by a siliceous layer. Journal of SolGel Science and Technology. 2003;26:1151-1157.

14. Lee KY. Mooney DJ. Hydrogels for tissue engineering. Chem Rev. 2001;101:1869-1879.

15. Hoffman AS. Hydrogels for biomedical applications. Adv Drug Deliv Rev. 2002;43:3-12.

16. Bahrami SB, Kordestani SS, Mirzadeh H, Mansoori P. Poly (vinyl alcohol) - Chitosan blends: preparation, mechanical and physical properties. Iranian Polymer Journal. 2003;12:139-146.

17. Nam SY, Nho YC, Hong SH, Chae GT, Jang HS, Suh TS, Ahn WS, Ryu $\mathrm{KE}$, Chun HJ. Evaluations of poly (vinyl alcohol)/alginate hydrogels cross-linked by $\mathrm{y}$-ray irradiation technique. Macromolecular Research. 2004;12:219-224.

18. Mishra S, Bajpai R, Katare R, Bajpai AK. Radiation induced cross linking effect on semi -interpenetrating polymer networks of poly (vinyl alcohol). Express Polymer Letters. 2007;1:407-415.
19. Zain NAM, Suhaimi MS, Idris A. Development and modification of PVA - alginate as suitable immobilization matrix. Process Biochemistry. 2011;46:2122-2129.

20. Wu KY, Wisecarver KD. Cell immobilization using PVA crosslinked with boric acid. Biotechnol Bioeng. 1992;39:447-449.

21. Dave R, Madamwar D. Polymer of poly (vinyl alcohol)- boric acid for esterification in organic media. Indian Journal of Biotechnology. 2006:5(Suppl):368-372.

22. Kulkarni AR, Soppimath KS, Aminabhavi TM. Controlled release of diclofenac sodium from sodium alginate beads crosslinked with glutaraldehyde. Pharm Acta Helv. 1999;74:29-36.

23. Ostberg T, Vesterhus L, Graffner C. Calcium alginate matrices for oral multiple unit administration. Part 2. Effect of process and formulation factors on matrix properties. Int J Pharm. 1993;97:183-193.

24. Pillay V, Dangor DM, Govender T, Moopanar KR, Hurbans N. Drug release modulation from cross-linked calcium alginate microdiscs, 2: swelling, compression, and stability of the hydrodynamically-sensitive calcium alginate matrix and the associated drug release mechanisms. Drug Delivery. 1998;5:35-46.

25. Pillay V, Dangor CM, Govender T, Moopanar KR, Hurbans N. Ionotropic gelation: encapsulation of indomethacin in calcium alginate gel discs. $J$ Microencapsul. 1998;15:215-226.

26. Pillay R, Fassihi R. In vitro release modulation from crosslinked pellets for site-specific drug delivery to the gastrointestinal tract. I. Comparison of $\mathrm{pH}$-responsive drug release and associated kinetics. J Controlled Release. 1999;59:229-242.

27. Kulkarni AR, Soppimath KS, Aminabhavi TM, Dave AM, Mehta MH. Glutaraldehyde crosslinked sodium alginate beads containing liquid pesticide for soil application. J Control Release. 2000;63:97-105.

28. Kim YJ, Yoon KJ, Ko SW. J Appl Polym Sci. 2000;78:1797-1804.

29. Tripathy T, Pandey SR, Karmakar NC, Bhagat RP, Singh RP. Eur Polym J. 1999;35:2057-2072

30. Beebe DJ, Moore JS, Bauer JM, Liu Q, Yu RH, Devadoss C, Jo BH. Functional hydrogel structures for autonomous flaw control inside micro- fluidic channels. Nature. 2000;404:588-590.

31. Shahinpoor M. J. Micro-elecctro - mechanics of ionic polymer gels as electrically controllable artificial muscles. Intell Mater Syst Struct. 1995;6:307-314.

32. Brock D, Lee WJ. A dynamic model of a linear actuator based on polymer Hydrogels. Intel Mater System Struct. 1994;5:764-771.

33. Helfferich F. Ion exchange. New York: McGraw-Hill, 1962:5.

34. Grodzinsky AJ, Grinshaw PE. Elctrically and chemically controlled hydrogels, for drug delivery. Pulsed and Self-Regulated Drug Delivery. 1990:47-64

35. Peppas NA, Brannon - Peppas L. Solute and Penetrant diffusion in swellable polymers. IX. The mechanism of drug release from $\mathrm{pH}$ sensitive swelling -controlled systems. J Control Release. 1989:267274.

36. Eisenberg SR. The kinetics of chemically induced non equilibrium swelling of articular cartilage and corneal stroma. J Biomed Eng. 1987;109:79-89.

37. Myers ER, Lai WM, Mow VC. A continuum theory and an experiment for the ion-induced swelling behavior of articular cartilage. J Biomech Eng. 1984;106:151- 158. 
38. Okano K, Bac YH, Kim SW. "Temperature responsive controlled drug delivery." Pulsed and self- regulated drug delivery pulsed and selfregulated Drug Delivery. 1990:17-46.

39. Kim JO, Park JK, Kim JH, Jin SG, Yonga CS, Li Dx, Choi HG. Development of Poly (vinyl alcohol) - sodium alginate gel-matrix -based wound dressing system Containing Nitrofurazone. Int J Pharm. 2008;359:79-86.

40. Chhatri A, Bajpai AK, Shandhu SS, Jain N, Biswas, J. Cryogenic fabrication of salvon loaded macroporous blends of alginate and Poly(vinyl alcohol) (PVA). Swelling, deswelling and antibacterial behaviors. Cabohydr Polym. 2011;83:876-882.

41. Mansur HS, Orefice RL, Mansur AAP. Characterization of Poly (vinyl alcohol)/ Poly (ethylene glycol) hydrogels and PVA - derived hybrids by small -angle $x$-Ray Scattering and FTIR spectroscopy. Polymer 2004; 45:7193-7202.
42. Sonali K, Udayabhanu MJ, Karthik KT, Rebecca G, David KM. Permance evalution of nanoclay enriched anti-microbial hydrogels for biomedical application. Heliyon. 2016;2:e00072.

43. Kamouna EA, Kenawy ERS, Tamer TM, Meligy MAE, Eldin MSM. Poly (vinyl alcohol)-alginate physically crosslinked hydrogel membranes for wound dressing applications: Characterization and bio-evaluation. Arabian Journal of Chemistry. 2015;8:38-47.

44. Zho Y, Su H, Fang L, Tan T. Superabsorbent hydrogels from poly(aspartic acid) with salt-, temperature- and $\mathrm{pH}$-responsiveness properties. Polymer. 2005;46:5368-5376.

45. Raafat Al, Eid M, El-Arnaouty MB. Radiation synthesis of superabsorbent CMC based hydrogels for agriculture applications. Nuclear Instrument and Methods in Physics Research Section B Beam Interactions with Materials and Atoms. 2012;283:71-76. 